\title{
Depression, Anxiety and Endometriosis: A systematic review and meta-analysis.
}

\author{
Esther van Barneveld ${ }^{1}$, Jessica Manders ${ }^{2}$, Frits van Osch ${ }^{2}$, Mikal van Poll ${ }^{2}$, Linda Visser ${ }^{3}$, \\ Lennie Hanegem ${ }^{1}$, Arianne Lim $^{1}$, Marlies Bongers ${ }^{1}$, and Carsten Leue ${ }^{1}$ \\ ${ }^{1}$ Maastricht UMC+ \\ ${ }^{2}$ Maastricht University \\ ${ }^{3}$ Zuyderland Medisch Centrum Heerlen
}

September 10, 2020

\begin{abstract}
Background: The extent of endometriosis is not directly related to the degree of symptoms, and recurrence of symptoms occurs frequently. Given that, an association with psychological distress, as in depression and anxiety disorders, is suggested. Objective: To explore the strength of the associations between endometriosis and depression or anxiety and to review potential correlating factors. Search Strategy: A literature search was carried out using the electronic databases Embase, PubMed, Web-of-science and PsycINFO. Search terms related to depression, anxiety and endometriosis were combined resulting in 1,837 records. Selection criteria: Articles describing an association between endometriosis and depression or anxiety by using validated assessment tools, structured psychiatric interviews or a documented diagnosis were included. Data collection and Analysis: With 47 articles a systematic qualitative review was performed. Seventeen studies were eligible for meta-analysis. Main Results: In the meta-analysis, endometriosis patients experienced significantly more symptoms of depression (SMD of 0.71 (95\%CI 0.36, 1.06) and anxiety (SMD $0.60(95 \%$ CI $0.35,0.84)$ ) compared to healthy controls, but no differences were found comparing endometriosis patients with chronic pelvic pain patients without endometriosis. Besides the effect of pain, other correlating factors included age, quality of life, quality of sleep, fatigue, sexual function, gastrointestinal symptoms, comorbidity, selfesteem, emotional self-efficacy, coping style, social adjustment, pain imagery and pain sensitization. Conclusion: Endometriosis is associated with depression and anxiety. Therefore, an integrated patient-centred approach to medical, psychological and sexual issues is suggested as this may positively influence the perception of symptoms, treatment adherence, quality of life, prognosis and health care costs.
\end{abstract}

\section{Tweetable abstract:}

In a systematic review and meta-analysis, endometriosis is associated with depression and anxiety.

Keywords: Anxiety, Depression, Endometriosis, Pain, Psychosomatic symptoms.

\section{Introduction}

Endometriosis is defined as an estrogen-dependent condition with presence of endometrium-like tissue outside the uterus [1]. The prevalence has been estimated between $2 \%$ to $10 \%$ in women of reproductive age and up to $50 \%$ in women with chronic pelvic pain (CPP) or fertility problems $[2,3]$. A combination of retrograde menstruation, defective immune clearance and changes in the peritoneal environment that stimulate cell growth is the most widely accepted explanation with regard to etiopathogenic mechanisms [4]. Dysmenorrhea, CPP, dyspareunia, fatigue/weariness and infertility are the leading symptoms [5,6,7], and the non-specific presentation of these symptoms often causes a delay concerning diagnosis [8-10]. Severity of the disease, pelvic pain, infertility, and a higher number of years since diagnosis are associated with higher 
costs of societal relevance, as symptoms affect physical, mental, sexual, and social well-being, as well as work productivity [11-13]. Furthermore, the extent of endometriosis is not directly related to the degree of symptoms [14] and recurrence of symptoms after surgical or medical interventions occurs frequently [15]. Hence, the perception of symptoms may be associated with psychological distress, such as in depression and anxiety disorders $[16,17]$. Depression and anxiety disorders are classified by the DSM-V psychiatric diagnostic criteria [18], and the global prevalence of depressive and anxiety disorders ranges from $4.5-7 \%$ and $5.5-6 \%$ respectively in women of reproductive age [19]. A relationship between depression, anxiety and endometriosis has been described from 1979 onward [20]. Demographic characteristics, social and disease-specific factors may predict psychological ill-health in endometriosis patients and could therefore lead to potential prediction models for the risk of developing depression or anxiety disorders in these patients.

The aim of this systematic review is to give an overview of what is known about the association between endometriosis and symptoms of depression or anxiety regarding its strength and direction, and to further examine which factors are associated. In addition, this review may help to elucidate the importance of psychiatric screening and to evaluate which patients are vulnerable for developing depression or anxiety disorders. This is important for clinical practice since the presence of anxiety and depression may influence the perception of symptoms, the prognosis, compliance with treatment and quality of life [21].

\section{Methods}

This systematic review was registered in PROSPERO (CRD42018106983) and was conducted following the PRISMA guidelines [22,23].

In- and exclusion criteria

Full length original articles meeting the following criteria were included:

- Including patients with suspected endometriosis corroborated by physical examination and imaging techniques and/or proven by laparoscopy;

- Using a validated multi-item scale or structured diagnostic interview for assessment of depressive symptoms and/or anxiety, or a registered diagnosis of depression or anxiety disorder (DSM or ICD code)*.

- Reporting an association between endometriosis and depression and/or anxiety;

- Peer reviewed journal articles published in English.

Animal studies, reviews, abstracts and expert opinions were excluded.

*DSM or ICD codes for depression or anxiety disorder are given by a professional and therefore most likely (in the past) followed by a structured diagnostic interview.

Literature search A systematic literature search was performed in PubMed, Embase, PsychInfo and Web of Science until the $16^{\text {th }}$ of June 2020. All studies that were published by that date were included. The detailed query is listed in the appendix $[\mathbf{S 1}]$. Search terms used were related to endometriosis, depression and anxiety. First, duplicates were removed. Three reviewers [EB, JM and MP] independently reviewed titles and abstracts and selected articles were reviewed on full text. Disagreements were handled by discussion and a third opinion [LV].Risk of bias assessment

Assessing the risk of bias, the Newcastle - Ottawa quality assessment scale for cohort studies and case control studies was used [24] as advised by The Cochrane Reviewers' Handbook [25]. In studies not including a control group, the checklist for reporting case series as published by Kempen (2011), was used [26].

Data selection and analysis

Articles were screened on reporting an association between endometriosis and depressive or anxiety symptoms. Furthermore, factors correlated with or contributing to this association were listed. Data from studies using validated outcome measures and reporting a mean and standard deviation (SD) concerning depression or anxiety scores in endometriosis patients compared with a control group, were pooled. The corresponding 
author was contacted if a mean and/or SD was not provided in the article, and additional data were added to pooling. Values were not included when not following a normal distribution. A random effects meta-analysis was carried out using STATA version 14 Software. Because of the heterogeneity in assessment tools, a standardized mean difference (SMD) with a $95 \%$ confidence interval (CI) was calculated. The heterogeneity was tested through I-squared tests with a significance level of 5\%. Mean age (and SD) of cases and controls are provided in order to assess comparability.

\section{Results}

Selection process The database search initially identified 1,837 records. After removal of duplicates and adding articles from reference lists, 1,289 remained for screening on title and abstract. 127 articles were assessed on full text. Consensus was obtained in $90 \%$, the remaining $10 \%$ were handled by discussion and a third opinion. Finally, 47 articles were included and a systematic qualitative review was performed [27-73]. Due to variations in study design, lack of control groups, different methods of measuring outcome and due to missing data, only 17 articles were eligible for data-pooling and meta-analysis $[28,29,35,38,43,46,38,51,54$ $56,57,60-62,67,68]$. Figure 1 shows a flowchart of the literature review process.

\section{Study characteristics}

An overview of the included articles, study design, sample size, population characteristics, measurement tools, results and factors correlated to anxiety and depression in endometriosis patients is listed in the appendix S2 [27-73]. We have included 41 studies with a cross-sectional design, three longitudinal cohort studies and three retrospective cohort studies. Most studies (52\%) originated from Europe, $26 \%$ from the United States of America or Canada, 15\% from South and central America. The remaining articles (7\%) originated from Asia, Africa or Oceania. Eleven of the included studies were published in the current year 2020 .

\section{Quality assessment}

An overview concerning risk of bias ascertained for each article is listed in the appendix [S3 ]. Overall, biases were mostly caused by study design (not including a healthy control group) and patient selection as most studies included women in tertiary referral centres. Most case series lacked describing a hypothesis or did not discuss the biological plausibility of the hypothesis in the light of reports' observations [26]. Cohort studies and case control studies, as assessed by the NOS scale [25], most frequently used hospital controls instead of community controls, and missing data was poorly reported.

\section{Assessment tools}

Forty studies included in this systematic review used a self-reporting validated outcome measurement tool and two studies performed a structured diagnostic interview for reporting either depressive or anxiety symptoms or both. Five studies reported a depression or anxiety disorder based on medical records (ICD-9 diagnoses). Various outcome measures were used of which the details are listed in appendixS4 [74-93]. With regard to the assessment of depressive symptoms, the Hospital Anxiety and Depression Scale (HADS) or Becks Depression Inventory (BDI) were most frequently used $[76,83]$. Concerning assessment of anxiety symptoms, the most commonly used tools were the HADS or the State-Trait Anxiety Inventory (STAI) [83,92]. Assessment of anxiety symptoms included the evaluation of either general, state, trait and/or phobic anxiety. Instruments developed for the global assessment of anxiety focus on the assessment of mood, cognition and behaviour, whereas tools for assessing phobic anxiety more often include somatic symptoms of anxiety [94]. State anxiety questionnaires evaluate anxiety as a current emotional state, whereas trait anxiety questionnaires evaluate individual differences in anxiety as a personality trait [95].

\section{Study subjects}

A total of $1,933,846$ subjects were reviewed, including 154,725 endometriosis patients, 1,778,317 healthy controls, 418 CPP patients without endometriosis and 386 infertile women without endometriosis. For the comparison of patient groups, different types of methods were used. Twenty-one studies inves- 
tigated anxiety and depression symptoms in endometriosis patients without including a control group $[27,33,34,36,37,39-42,45,47,49,50,52,58,59,63,65,66,69,70,72,73]$. Twenty-six studies compared endometriosis patients with a group of either healthy controls $[30,32,35,38,39,46,51,55]$, CPP patients without endometriosis $[29,48,54,60,67]$, infertile patients without endometriosis [61,64] or a combination of control groups $[28,43,44,53,56,57,62,68,71]$. Four studies compared endometriosis patients with pain symptoms to pain-free endometriosis patients $[28,34,35,47]$. Two studies compared endometriosis patients with and without infertility $[59,62]$.

\section{Depression}

Depending on the outcome measure that was used, depressive symptoms occurred in 10-86\% of patients with endometriosis. Symptoms were reported to be mild in $13-68 \%$ and moderate to severe in $2-64 \%$ of patients. In comparison, depressive symptoms occurred in 7-19\% of healthy controls in the included studies. Chen et al (2016) reported an increased risk of developing a major depression (HR: 1.56, 95\% CI:1.24-1.97) and any depressive disorder (HR: 1.44, 95\% CI: 1.25-1.65) for women with endometriosis compared with healthy controls [31].

Most case-control studies, reported that symptoms of depression occurred significantly more often in endometriosis patients compared with healthy controls $[28,30-32,35,39,43,46,51,56,62,66,68]$ but not compared with CPP patients without endometriosis $[29,43,48,53,54,56,57,60,62,67]$. On the contrary, four studies did not find a higher depression rate in endometriosis patients compared with healthy controls $[38,44,57,71]$. Two studies found no difference in depression symptoms in pain-free endometriosis patients compared with healthy controls $[28,35]$. A study by Stratton et al (2015) found a higher rate for depression in CPP patients compared with endometriosis patients [68].

Figure 2a shows pooled data including 11 studies comparing 513 endometriosis patients with 600 healthy controls. Meta-analysis reveals a significant higher symptom score for depression in patients with endometriosis (SMD 0.71 (95\% CI 0.36 - 1.06). Figure 2b shows pooled data including 11 studies comparing 284 endometriosis patients with $407 \mathrm{CPP}$ patients without endometriosis. Meta-analysis shows no significant difference in depression scores between the two groups (SMD -0.01 (95\% CI -0.17-0.15)). The mean scores and SD of age and results on validated outcome questionnaires per study are shown in Table 1 and 2.

Anxiety Depending on the outcome measurement, anxiety occurred in 10-79\% of patients with endometriosis. Symptoms of anxiety were reported mild in $22-79 \%$ and moderate/severe in $23-64 \%$ of patients. In comparison, anxiety occurred in 6-14\% of healthy controls in the studies included. Chen et al (2016) reported an increased risk for women with endometriosis of developing anxiety disorders (HR: 1.44, 95\% CI: 1.22-1.70) compared with healthy controls [31].

Twelve studies reported higher anxiety scores (including state, trait and phobic anxiety) in endometriosis patients compared with healthy controls $[28,31,32,35,39,43,44,46,51,56,66,68]$. In nine studies no differences in anxiety scores were found between endometriosis patients and CPP patients [29,43,44,54,56,57,60,62,67]. However, four studies did not report any difference between endometriosis patients and healthy controls concerning anxiety scores $[30,38,57,62]$. Quiñones et al (2015) reported higher trait anxiety in endometriosis patients compared with healthy controls, but no difference in state anxiety. Two studies reported a controversial difference in anxiety scores between endometriosis patients and CPP patients without endometriosis $[48,68]$.

Figure 2c shows pooled data including 12 studies comparing 544 endometriosis patients with 636 healthy controls. Meta-analysis shows significant higher anxiety scores in patients with endometriosis (SMD 0.60 (95\% CI 0.35-0.84). Figure 2d shows pooled data including 11 studies comparing 284 endometriosis patients with $407 \mathrm{CPP}$ patients without endometriosis. Meta-analysis reveals no significant difference in anxiety scores between these groups (SMD -0.02 (95\%CI -0.22-0.18). In this meta-analysis the state anxiety score (but not the trait anxiety score) is used when the STAI questionnaire was assessed.

Correlating factors with depression and anxiety in endometriosis patients. 
The role of endometriosis related pain and the association with depression and anxiety was the most commonly described factor. Facchin et al (2017) reported an increase of 9.6\% in depression and 10.6\% increase in anxiety symptoms in case of endometriosis-related predictors (hormonal treatment, surgical interventions, infertility, time from diagnosis, and pain severity) [36]. Four out of five studies comparing endometriosis patients with pain with pain-free endometriosis patients found significant higher rates of depression, up to $86 \%$ in the pain-group $[28,35,47,62]$. As-Sanie et al (2012) and Facchin et al (2015) also found significant differences for anxiety scores between these groups. However, Eriksen et al (2008) reported, except for slightly higher anxiety scores in the pain group, no significant correlation between the degree of pain and depression or anxiety scores [34]. There was no consensus on the association concerning the type of pain (CPP, dysmenorrhea, dyspareunia).

Infertility was the second most investigated factor that was hypothesized to contribute to depression or anxiety in endometriosis patients. However, comparison of infertile with fertile endometriosis patients [59] or with infertile patients without endometriosis $[61,62]$ did not show any significant difference on depression or anxiety symptoms. In addition, Shaw et al, 1995 described that in women with endometriosis related pain, depression occurred more frequently (23.5\%) compared with endometriosis patients with infertility (13\%) $[62]$.

Studies that investigated other factors than pain or infertility, reported that higher scores of depression or anxiety in endometriosis patients were correlated to poorer quality of sleep [27], fatigue [52], poorer quality of life [32,49,50,52], gastrointestinal symptoms [70], lower self-esteem [36], lower emotional self-efficacy [36], lower sexual functioning [32,51], dysfunction on social adjustment [54], pain imagery [42] and clinical signs of pain sensitization [68]. In addition, it was reported that patients who used positive coping strategies had less depression [33,34]. Furthermore, in the included studies, it was described that depression and anxiety occurred more frequently in patients with advanced age $[38,63]$, lower cortisol levels [55], metabolic syndrome [31] and comorbid pain syndromes [65], and, the presence of depression and anxiety was independently associated with increased costs [45].

No correlation was found between depression or anxiety and endometriosis stage [30,63], being childless [37], experiencing no pain relief after surgery [41] or oral contraceptive therapy [72]. Correlations of anxiety and depression in endometriosis patients concerning time of diagnosis were described contradictorily $[36,63,69]$.

\section{Discussion Main Findings}

The aim of this systematic review was to give an overview on the association between endometriosis and symptoms of depression and anxiety and the factors that are correlated to this association. A total of 47 articles comprising 1,933,846 subjects were reviewed. Data from 17 studies using validated outcome measures was pooled for a random effects meta-analysis comparing 677 endometriosis patients with 636 healthy controls and $407 \mathrm{CPP}$ patients without endometriosis. Reviewed articles showed a prevalence ranging from 10-86\% for depression and 10-79\% for anxiety, whereas the global prevalence of depressive and anxiety disorders ranges from 4.5-7\% and 5.5-6\% respectively in women of reproductive age [19]. Derived from the pooled data, the standardized mean differences in anxiety and depression scores is significantly higher in studies of endometriosis patients compared with healthy controls but not in comparison to CPP patients. Hence, this elevated prevalence, seems to be not specific for endometriosis but is comparable to women with other conditions representing CPP. This systematic review included mostly studies with a cross-sectional design and does not allow for analysis of causal inference. Nevertheless, two studies with a longitudinal design showed an elevated likelihood of developing depression and anxiety disorders in endometriosis [31,39]. In addition, women with a previously diagnosed depression or anxiety disorder, were more likely to be later diagnosed with endometriosis [31,39]. Regrettably, the authors did not evaluate the impact of endometriosis related factors such as pain on the risk of mood disorders.

The majority of cross-sectional studies investigating pain as a dependent factor, reported a positive association between pain intensity and scores for depressive symptoms and anxiety. This is a well-known phenomenon in pain being part of functional psychosomatic syndromes [103]. In endometriosis studies however, there was 
no consensus on the relation between the type of pain (CPP, dysmenorrhea, dyspareunia) and affective symptoms. Facchin et al. (2015) was the first to test the 'disease-focused hypothesis' and the 'pain-focused hypothesis' in endometriosis by comparing asymptomatic endometriosis patients, endometriosis patients with pelvic pain and healthy pain-free controls. Their findings offered the conclusion that painless endometriosis does not necessarily involve psychological pain or discomfort. However, the researchers did not control for the effect of diagnostic and demographic factors. Other studies included in this review suggest that factors correlated to affective symptoms in endometriosis patients include age, quality of life, quality of sleep, fatigue, sexual function, gastrointestinal symptoms, comorbidity, self-esteem, emotional self-efficacy, coping style, social adjustment, pain imagery and pain sensitization. This indicates that other factors are involved in symptom burden and treatment refractoriness in women suffering from endometriosis. As in other complex patients, these aspects remain frequently undetected, which could lead to misdiagnosis and puzzled treatment pathways $[104,105]$.

\section{Strengths, limitations and interpretation}

In addition to earlier published reviews concerning the association between endometriosis and psychological problems $[21,96]$, the current review specifically provides an up to date overview with regard to both depressive and anxiety symptoms in these patients. Furthermore, we provided information concerning factors that correlate with depression and anxiety symptoms in endometriosis. Reporting of these correlations is important to recognise vulnerable patients in clinical practice. As research demonstrated the reliability of non-surgical diagnosis of endometriosis, we also included studies including patients with a clinical diagnosis of endometriosis, which made it possible to generate a large number of studies. In contrast to Gambadauro et al, our review excluded studies with self-reported diagnoses of depression and studies using non standardized assessment methods, to limit the risk of over-reporting. The meta-analysis included solely studies using a standardized outcome measure to limit heterogeneity in the results. The overall SMD of studies comparing endometriosis patients with CPP patients without endometriosis showed an I-squared of $0 \%(\mathrm{p}=0.798)$ for depression scores and an I-squared of $33.2 \%(\mathrm{p}=0.134)$ for anxiety scores, which means that the heterogeneity between these studies was low. Nevertheless, heterogeneity between studies comparing endometriosis patients with healthy controls was relatively high: I-squared $84.6 \%(\mathrm{p}<0.001)$ for depression scores and I-squared $68.1 \%(\mathrm{p}<0.001)$ for anxiety scores. This makes it difficult to compare and generalize the study outcomes. Hence, strategies of research groups and their assessment tools need to be standardized to produce robust and reliable results for meta-analyses. However, a sub-analysis including only studies using the HADS as outcome measures, did not change outcome nor improved I-squared results, meaning that heterogeneity was probably caused by differences in demographic or other factors. Furthermore, this review has some other limitations. First, including articles in English only limits the number of included studies. Risks of bias were mostly caused by study design and patient selection as most studies included women in tertiary referral centres. This could have led to an over-presentation of symptoms compared to patients in the general population. Although validated, the used assessment tools are predominantly self-assessment questionnaires, which gives an indication of a depressive or anxious state but does not provide a valid diagnosis. Studies using reported ICD-9 diagnoses given by professionals could have led to under-reporting of depression and anxiety complaints as those might have not received an official diagnosis. Another important limitation is the variation in types of anxiety disorders that were pooled in the meta-analysis. Screening tools for anxiety disorders usually provide lower sensitivity and specificity than tools for depressive disorders, as anxiety disorders have more heterogeneous symptoms (state, trait or phobic anxiety) [94].

\section{Implications for further research and treatment}

There is a need to understand the consequences of affective symptoms on pain amplification or pain reduction during endometriosis treatment, which is very important in clinical practice. Chronic pelvic pain improvement alone does not automatically improve depressive symptoms and this assumption produces delays concerning psychosomatic care $[97,98]$. However, improvements in depression, anxiety and pain catastrophizing, can influence pain perception [99] and, therefore, improve quality of life as well as sexual and social functioning which in turn may reduce societal relevant health care costs $[8,13]$. Hence, an integrated and patient-centred 
approach to medical, psychological and sexual issues is suggested $[51,106]$. Integration of care is deemed necessary at the hospital level and between hospital and primary care, and a multi-component strategy should include efforts to combat stigmatization concerning psychiatric comorbidity [100]. With regard to symptom formation (or in other words how symptoms impact on symptoms as in pain sensitization), the Experience Sampling Method (ESM) might be able to unravel how affective complaints and pain are related over time [107]. ESM is an ecological momentary assessment tool, which could help to provide information on symptoms in the context of daily life including psychological symptoms and sexuality [108]. This may help to overcome the limitations of current retrospective questionnaires [101].

\section{Conclusion}

This systematic review supports the assumption that symptoms of depression and anxiety in endometriosis patients are related to chronic pain. Anxiety and depression may influence pain perception in endometriosis patients, and, currently, there is no consensus regarding which condition comes first. Broad correlating factors should be further investigated in order to predict the risk of developing symptoms of depression and anxiety in endometriosis patients. Besides medical endometriosis treatment as well as behavioural pain management, the improvement of emotion regulation skills should be a treatment goal in endometriosis patients as well [102].

\section{Acknowledgements}

We thank Gregor Franssen, specialist scientific information at the Maastricht University library, for his help with the literature search. We thank all authors willing to provide their data for meta-analysis.

\section{Disclosure of Interests}

None.

\section{Contribution to authorship:}

All authors accept responsibility for this paper.

E. van Barneveld : search, review of articles, meta-analysis, interpretation of data, writing of article.

J. Manders : review of articles, writing of article.

F. van Osch : statistics, meta-analysis.

M. van Poll : review of articles.

L. Visser : providing study protocol, identifying relevant search terms, third opinion in review of articles.

N. van Hanegem : study protocol, interpretation of data for clinical practice, contribution to writing of article.

A.C. Lim : study protocol, interpretation of data for clinical practice, contribution to writing of article.

M.Y. Bongers : study protocol, interpretation of data for clinical practice, contribution to writing of article.

C. Leue : study protocol, third opinion in review of articles, interpretation of data for clinical practice, contribution to writing of article.

\section{Funding}

No funding was provided.

\section{References}

[1] Kennedy S, Bergqvist A, Chapron C, D'Hooghe T, Dunselman G, Greb R, Hummelshoj L, Prentice A, Saridogan E. ESHRE guideline for the diagnosis and treatment of endometriosis. Hum Reprod 2005; 20(10):2698-2704. 
[2] Eskenazi B, Warner ML. Epidemiology of endometriosis.Obstet Gynecol Clin North Am 1997; 24(2):235258.

[3] Meuleman C, Vandenabeele B, Fieuws S, Spiessens C, Timmerman D, D'Hooghe T. High prevalence of endometriosis in infertile women with normal ovulation and normospermic partners. Fertil Steril 2009; 92(1):68-74.

[4] Burney RO, Guidice LC. Pathogenesis and Pathophysiology of Endometriosis. Fertil Steril 2012; 98(3).

[5] Bellelis P, Dias JA Jr, Podgaec S, Gonzales M, Baracat EC, Abrão MS. Epidemiological and clinical aspects of pelvic endometriosis - a case series. Rev Assoc Med Bras 2010; 56:467-471.

[6] Davis GD, Thillet E, Lindemann J. Clinical characteristics of adolescent endometriosis. J Adolesc Health 1993; 14:362-368.

[7] Lemaire GS. More than just menstrual cramps: symptoms and uncertainty among women with endometriosis. J Obstet Gynecol Neonatal Nurs 2004; 33:71-79.

[8] Nnoaham KE, Hummelshoj L, Webster P, d'Hooghe T, Cicco Nardone de F, Cicco Nardone de C et al. Impact of endometriosis on quality of life and work productivity: a multicentre study across ten countries. Fertil Steril 2011; 96(2):366-373.

[9] Hadfield R, Mardon H, Barlow D, Kennedy S. Delay in the diagnosis of endometriosis: a survey of women from the USA and the UK. Hum Reprod 1996;11(4):878-80.

[10] Husby GK, Haugen RS, Moen MH. Diagnostic delay in women with pain and endometriosis. Acta Obstet Gynecol Scand 2003; 82(7):649-53.

[11] Chaman-Ara K, Bahrami MA, Moosazadeh M, Bahrami E. Quality of life in women with endometriosis: a systematic review and meta-analysis. WCRJ 2017; 4(1):e839.

[12] Culley L, Law C, Hudson N, Denny E, Mitchell H, Baumgarten M, et al. The social and psychological impact of endometriosis on women's lives: a critical narrative review. Hum Reprod Update 2013; 19(6):625639.

[13] Simoens S, Dunselman G, Dirksen C, Hummelshoj L, Bokor A, Brandes I, et al. The burden of endometriosis: costs and quality of life of women with endometriosis and treated in referral centres. Hum Reprod 2012; 27:1292-1299.

[14] Vercellini P, Fedele L, Aimi G, Pietropaolo G, Consonni D, Crosignani PG. Association between endometriosis stage, lesion type, patient characteristics and severity of pelvic pain symptoms: a multivariate analysis of over 1000 patient. Hum Reprod 2007; 22(1):266-271.

[15] Becker CM, Gattrell WT, Gude K, Singh SS. Reevaluating response and failure of medical treatment of endometriosis: a systematic review.Fertil Steril 2017; 108:125-36.

[16] Laganà AS, La Rosa VL, Rapisarda AMC, Valenti G, Sapia F, Chiofalo B, et al. Anxiety and depression in patients with endometriosis: impact and management challenges. Int $J$ Womens Health 2017; 9:323-330.

[17] Vitale SG, Petrosino B, La Rosa VL, Rapisarda AMC, Laganà AS. A Systematic Review of the Association Between Psychiatric Disturbances and Endometriosis. J Obstet Gynaecol Can 2016; 38(12):1079-1080.

[18] Diagnostic and statistical manual of mental disorders: DSM-V $5^{\text {th }}$ edition, American Psychiatric Association, 2013.

[19] Depression and Other Common Mental Disorders: Global Health Estimates. Geneva: World Health Organization, 2017. [20] Renaer M, Vertommen H, Nijs P, Wagemans L, Van Hemelrijck T, Psychological aspects of chronic pelvic pain in women. Am J Obstet Gynecol 1979; 134(1):75-80. 
[21] Pope CJ, Sharma V, Sharma S, Mazmanian D. A Systematic Review of the Association Between Psychiatric Disturbances and Endometriosis.J Obstet Gynaecol Can 2015; 37(11):1006-1015.

[22] PROSPERO International prospective register of systematic reviews, Affective symptoms and endometriosis: a systematic review. Available from: https://www.crd.york.ac.uk/prospero/display_record.php?RecordID=106983

[23] Moher D, Liberati A, Tetzlaff J, Altman DG. PRISMA Group, Preferred reporting items for systematic reviews and meta-analyses: the PRISMA statement. PLoS Med 2009; 6(7):e1000097.

[24] Wells G, Shea B, O'Connell D, Robertson J, Peterson J, Welch V, et al. The Newcastle-Ottawa Scale (NOS) for Assessing the Quality of Nonrandomized Studies in Meta-Analysis. www.lri.ca.

[25] Higgins JPT, Thomas J, Chandler J, Cumpston M, Li T, Page MJ, et al. Cochrane Handbook for Systematic Reviews of Interventions version 6.0 (updated July 2019). Cochrane, 2019. Available from www.training.cochrane.org/handbook.

[26] Kempen JH. Appropriate Use and Reporting of Uncontrolled Case Series in the Medical Literature. Am J Ophthalmol 2011: 151(1); 7-10.

[27] Arion K, Orr NL, Noga H, Allaire C, Williams C, Bedaiwy MA, et al. Quantitative Analysis of Sleep Quality in Women with Endometriosis.J Womens Health 2020. DOI: 10.1089/jwh.2019.8008

[28] As-Sanie S, Harris RE, Napadow V, Kim J, Neshewat G, Kairys A, et al. Changes in regional gray matter volume in women with chronic pelvic pain: A voxel-based morphometry study. PAIN2012:153;1006-1014.

[29] Brooks T, Sharp R, Evans S, Baranoff J, Esterman A. Predictors of Depression, Anxiety and Stress

Indicators in a Cohort of Women with Chronic Pelvic Pain. Journal of Pain Research 2020:13 527-536.

[30] Cavaggioni G, Lia C, Resta S, Antonielli T, Benedetti Panici P, Megiorni F, et al. Are Mood and Anxiety Disorders and Alexithymia Associated with Endometriosis? A Preliminary Study, Biomed Res Int 2014:786830.

[31] Chen LC, Hsu JW, Huang KL, Bai YM, Su TP, Li CT, et al. Risk of developing major depression and anxiety disorders among women with endometriosis: A longitudinal follow-up study. J Affect Disord2016; 190:282-285.

[32] De Graaff AA, Van Lankveld J, Smits LJ, Van Beek JJ, Dunselman GAJ. Dyspareunia and depressive symptoms are associated with impaired sexual functioning in women with endometriosis, whereas sexual functioning in their male partners is not affected. Hum Reprod2016; 31(11):2577-2586.

[33] Donatti L, Ramos DG, Andres MD, Passman LJ, Podgaec S. Patients with endometriosis using positive coping strategies have less depression, stress and pelvic pain. Einstein-Sao Paulo 2017; 15(1):65-70.

[34] Eriksen HLF, Gunnersen KF, Sørensen JA, Munk T, Nielsen T, Knudsen UB. Psychological aspects of endometriosis: Differences between patients with or without pain on four psychological variables. Eur $J$ Obstet Gynecol Reprod Biol 2008; 139(1):100-105.

[35] Facchin F, Barbara G, Saita E, Mosconi P, Roberto A, Fedele L, et al. Impact of endometriosis on quality of life and mental health: pelvic pain makes the difference. J Psychosom Obstet Gynecol2015; 36(4):135-141.

[36] Facchin F, Barbara G, Dridi D, Alberico D, Buggio L, Somigliana E, et al. Mental health in women with endometriosis: searching for predictors of psychological distress. Hum Reprod 2017; 32(9):1855-1861.

[37] Facchin F, Buggio L, Dridi D, Vercellini P. A woman's worth: The psychological impact of beliefs about motherhood, female identity, and infertility on childless women with endometriosis. J. Health Psychol. 2019. https://doi.org/10.1177/1359105319863093 
[38] Friedl F, Riedl D, Fessler S, Wildt L, Walter M, Richter R, et al. Impact of endometriosis on quality of life, anxiety, and depression: an Austrian perspective. Arch Gynecol Obstet 2015; 292(6):1393-1399.

[39] Gao M, Koupil I, Sjöqvist H, Karlsson H, Lalitkumar S, Dalman C, et al. Psychiatric comorbidity among women with

endometriosis: nationwide cohort study in Sweden. Am J Obstet Gynecol 2020. https://doi.org/10.1016/j.ajog.2020.02.033

[40] Ghai V, Jan H, Shakir F, Kent A. Identifying Preoperative Factors Associated with Nonresponders in Women Undergoing Comprehensive Surgical Treatment for Endometriosis. Journal of Minimally Invasive Gynecology 2020:27(1);141-147.

[41] González-Echevarría AM, Rosario E, Acevedo S, Flores I. Impact of coping strategies on quality of life of adolescents and young women with endometriosis. J Psychosom Obstet Gynecol 2018; 1-8.

[42] Graham CJ, Brown SL, Vincent K, Horne AW. International survey confirms that women with endometriosis-associated pain experience a high prevalence of pain imagery and coping imagery. European Journal of Obstetrics $\& 3$ Gynecology and Reproductive Biology, 2020:244;201-210.

[43] Grundström H, Gerdle B, Alehagen S, Berterö C, Arendt-Nielsen L, Kjølhede P. Reduced pain thresholds and signs of sensitization in women with persistent pelvic pain and suspected endometriosis.Acta Obstet Gynecol Scand 2019;98(3):327-336.

[44] Issa B, Onon TS, Agrawal A, Shekhar C, Morris J, Hamdy S, et al. Visceral hypersensitivity in endometriosis: a new target for treatment? Gut 2012; 61:367-372.

[45] Klein S, D'Hooghe T, Meuleman C, Dirksen C, Dunselman G, Simoens S. What is the social burden of endometriosis-associated symptoms? A prospective Belgian study, Reprod BioMed Online 2014; 28(1):116124 .

[46] Laganà AS, Condemi I, Retto G, Muscatello MRA, Bruno A, Zoccali RA, et al. Analysis of psychopathological comorbidity behind the common symptoms and signs of endometriosis, Eur J Obstet Gynecol Reprod Biol 2015; 194:30-33.

[47] Lorençatto C, Petta CA, Navarro MJ, Bahamondes L, Matos A. Depression in women with endometriosis with and without chronic pelvic pain, Acta Obstet Gynecol Scand 2006; 85(1):88-92.

[48] Low WY, Edelmann RJ, Sutton C. A psychological profile of endometriosis patients in comparison to patients with pelvic pain of other origins, J Psychosom Res 1993; 37(2):111-116.

[49] Márki G, Bokor A, Rigó J, Rigó A. Physical pain and emotion regulation as the main predictive factors of health-related quality of life in women living with endometriosis, Hum Reprod 2017; 32(7):1432-1438.

[50] McPeak AE, Allaire C, Williams C, Albert A, Lisonkova S. Pain Catastrophizing and Pain HealthRelated Quality-of-Life in Endometriosis. Clin J Pain 2018;34:349-356.

[51] Melis I, Litta P, Nappi L, Agus M, Melis GB, Angioni S. Sexual function in women with deep endometriosis: Correlation with quality of life, intensity of pain, depression, anxiety, and body image, Int J Sex Health 2015; 27(2):175-185.

[52] Mundo-López A, Ocón-Hernández O, San-Sebastián AP, Galiano-Castillo N, Rodríguez-Pérez O, ArroyoLuque MS, et al. Contribution of Chronic Fatigue to Psychosocial Status and Quality of Life in Spanish Women Diagnosed with Endometriosis. Int. J. Environ. Res. Public Health 2020:17(11);3831.

[53] Osório FL, Carvalho ACF, Donadon MF, Moreno AL, Polli-Neto O. Chronic pelvic pain, psychiatric disorders and early emotional traumas: Results of a cross sectional case-control study, World J Psychiatry 2016; 6(3):339-344. 
[54] Peveler R, Edwards J, Daddow J, Thomas E, Psychosocial factors and chronic pelvic pain: A comparison of women with endometriosis and with unexplained pain, J Psychosom Res 1996; 40(3):305-315.

[55] Quiñones M, Urrutia R, Torres-Reverón A, Vincent K, Flores I. Anxiety, coping skills and hypothalamuspituitary-adrenal (HPA) axis in patients with endometriosis, J Reprod Biol Health 2015; 3.

[56] Renaer M, Vertommen H, Nijs P, Wagemans L, Van Hemelrijck T. Psychological aspects of chronic pelvic pain in women, Am J Obstet Gynecol 1979; 134(1):75-80.

[57] Rocha MG, Gomes VA, Tanus-Santos JE, Rosa-e-Silva JC, Candido-dos-Reis FJ, Nogueira AA. Reduction of blood nitric oxide levels is associated with clinical improvement of the chronic pelvic pain related to endometriosis, Braz J Med Biol Res 2015; 48(4):363-369.

[58] Roomaney R, Kagee A, Heylen S. Biopsychosocial predictors of symptoms of depression in a sample of South African women diagnosed with endometriosis. Health Care Women Int 2019;26:1-22.

[59] Rossi V, Viozzi E, Tripodi F, Porpora MG, Simonelli C, Nimbi FM. Endometriosis, sexuality and satisfaction: A pilot study on women with and without infertility. Sexologies 2020:29(2);63-69.

[60] Roth RS, Punch M, Bachman JE. Psychological Factors in Chronic Pelvic Pain due to Endometriosis: A Comparative Study, Gynecol Obstet Invest 2011; 72(1):15-19.

[61] Shatford LA, Hearn MT, Yuzpe AA, Brown SE, Casper RF. Psychological correlates of differential infertility diagnosis in an in vitro fertilization program. Am J Obstet Gynecol, 1988:158(5);1099-107.

[62] Shaw RW, Waller KG. Endometriosis, pelvic pain, and psychological functioning, Fertil Steril 1995; 63(4):796-800.

[63] Sepulcri RP, Amaral VF. Depressive symptoms, anxiety, and quality of life in women with pelvic endometriosis, Eur J Obstet Gynecol Reprod Biol 2009; 142(1):53-56.

[64] Siedentopf F, Tariverdian N, Rücke M, Kentenich H, Arck PC. Immune Status, Psychosocial Distress and Reduced Quality of Life in Infertile Patients with Endometriosis. Am J Reprod Immunol 2008; 60(5):449-461.

[65] Smorgick N, Marsh CA, As-Sanie S, Smith YR, Quint EH. Prevalence of Pain Syndromes, Mood Conditions, and Asthma in Adolescents and Young Women with Endometriosis. J Pediatr Adol Gynec, 2013:26(3);171-175.

[66] Soliman AM, Surrey E, Bonafede M, Nelson JK, Castelli-Haley J. Real-World Evaluation of Direct and Indirect Economic Burden Among Endometriosis Patients in the United States. Adv Ther, 2018: 35(3);408423.

[67] Souza CA, Oliveira LM, Scheffel C, Genro VK, Rosa V, Chaves MF, et al. Quality of life associated to chronic pelvic pain is independent of endometriosis diagnosis-a cross-sectional survey. Health Qual Life Outcomes 2011; 9:41.

[68] Stratton P, Khachikyan I, Sinaii N, Ortiz R, Shah J. Association of Chronic Pelvic Pain and Endometriosis With Signs of Sensitization and Myofascial Pain, Obstet Gynecol 2015; 125(3):719-728.

[69] Surrey E, Soliman AM, Trenz H, Blauer-Peterson C, Sluis A. Impact of Endometriosis Diagnostic Delays on Healthcare Resource Utilization and Costs. Adv Ther , 2020:37;1087-1099.

[70] Turco LC, Scaldaferri F, Chiantera V, Cianci S, Ercoli A, Fagotti A, et al. Long-term evaluation of quality of life and gastrointestinal well-being after segmental colo-rectal resection for deep infiltrating endometriosis (ENDO-RESECT QoL). Arch Gynecol Obstet 2020; 301:217-228.

[71] Walker E, Katon W, Jones LM, Russo J. Relationship Between Endometriosis and Affective Disorder. Am J Psychiatry 1989; 146(3):380-381. 
[72] Yong PJ, Alsowayan N, Noga H, Williams C, Allaire C, Lisonkova S, et al. CHC for pelvic pain in women with endometriosis: Ineffectiveness or discontinuation due to side-effects. Hum. Reprod. Open , 2020:2;1-9.

[73] Youseflu S, Sadatmahalleh SJ, Khomami MB, Nasiri M. Influential factors on sexual function in infertile women with endometriosis: a path analysis. BMC Women's Health 2020:20(1).

[74] Hautzinger M, Bailer M, Hofmeister D, Keller F, Allgemeine Depressionsskala 2., uberarbeitete und neu normierte Auflage, 2012.

[75] Beck AT, Epstein N, Brown G, Steer RA. An inventory for measuring clinical anxiety: Psychometric properties, J Consult Clin Psychol 1988; 56(6):893-897.

[76] Beck AT, Steer RA, Ball R, Ranieri WF. Comparison of Beck Depression Inventories-IA and -II in Psychiatric Outpatients, J Pers Assess 1996; 67(3):588-597.

[77] Beurs de E, Zitman FG. The Brief Symptom Inventory (BSI): Reliability and validity of a practical alternative to SCL-90,Maandblad Geestelijke Volksgezondheid 2006; 61:120-141.

[78] Radloff LS. The CES-D scale a self-report depression scale for research in the general population. Appl. Psychol. Meas. 1977: 1(3): 385-401.

[79] Parkerson Jr GR, Broadhead WE, Tse CKJ. Complete Dissertation by Statistics Solutions, Duke Health Profile (The DUKE), Retrieved (13-01-2019) from https://www.statisticssolutions.com/duke-health-profilethe-duke/

[80] Pincus T, Rusu A, Santos R. Responsiveness and construct validity of the depression, anxiety, and positive outlook scale (DAPOS). Clin J Pain 2008; 24(5):431-7.

[81] Lovibond PF, Lovibond SH. The structure of negative emotional states: Comparison of the Depression Anxiety Stress Scales (DASS) with the Beck Depression and Anxiety Inventories. BehaP. Res. Ther1995; 33(3): 335-343.

[82] Spitzer RL, Kroenke K, Williams JB, Lowe B. A brief measure for assessing generalized anxiety disorder: the GAD-7. Arch Intern Med 2006;166:1092-1097.

[83] Zigmond AS, Snaith RP. The Hospital Anxiety and Depression Scale, Acta Psychiatr Scand 1983; 67(6):361-370.

[84] Maier W, Buller R, Philipp M, Heuser. The Hamilton Anxiety Scale: reliability, validity and sensitivity to change in anxiety and depressive disorders, J Affect Disord 1988; 14:61-68.

[85] Ware J, Kosinski M, Keller S. A 12-item Short-Form Health Survey: Construction of Scales and Preliminary Tests of Reliability and Validity, Med Care 1996; 34(3):220-233.

[86] John Wiley \& Sons, Handbook of Psychological Assessment, $5^{\text {th }}$ edition, Gary Groth-Marnat, 2009.

[87] Shaffer DFRC, Fisher MS, Lucas CP, Dulcan MK, Schwab-Stone ME. NIMH Diagnostic Interview Schedule for Children Version IV (NIMH DISC-IV): Description, Differences From Previous Versions, and Reliability of Some Common Diagnoses, J Am Acad Child Adolesc Psychiatry 2000; 39(1):28-38.

[88] Kroenke K, Spitzer RL, Williams JB. The PHQ-9. Validity of a brief depression severity measure. $J$ Gen Intern Med.2001;16:606-613.

[89] Zung WWK. Complete Dissertation by Statistics Solutions, Zung Self-Rating Anxiety Scale (SAS), from https://www.statisticssolutions.com/zung-self-rating-anxiety-scale-sas/

[90] Holi M. Assessment of psychiatric symptoms using the SCL-90, Department of Psychiatry Helsinki University Finland, 2003. 
[91] De jonghe J, Baneke J. The zung self-rating depression scale: a replication study on reliability, validity and prediction, Psychol Rep 1989; 64(3):833-834.

[92] Kvaal K, Ulstein I, Nordhus IH, Engedal K. The Spielberger State-Trait Anxiety Inventory (STAI): the state scale in detecting mental disorders in geriatric patients. Int J Geriatr Psychiatry2005; 20(7):629-634.

[93] Spielberger CD, Jacobs G, Crane R, Russel S, Westberry L, Barker E, et al. Preliminary manual for the State-Trait Personality Inventory. Unpublished manual, 1979, University of South Florida, Tampa.

[94] Rose M, Devine J. Assessment of patient-reported symptoms of anxiety. Dialogues Clin Neurosci . 2014 Jun; 16(2): 197-211.

[95] Spielberger CD, Gorsuch RL, Lushene RE. STAI Manual for the State-Trait Anxiety Inventory. California: Consulting Psychologists Press; 1970.

[96] Gambadauro P, Carli V, Hadlaczky G. Depressive symptoms among women with endometriosis: a systematic review and meta-analysis, Am J Obstet Gynecol 2018; Retrieved (18-01-2019) from https://doi.org/10.1016/j.ajog.2018.11.123

[97] Learman LA. Depressive symptoms among women with endometriosis: A systematic review and metaanalysis EDITORIAL COMMENT. Obstet Gynecol Surv 2019;74(4):213-214.

[98] Cagnacci A, Della Vecchia E, Xholli A. Chronic pelvic pain improvement: impact on quality of life and mood. GynecolEndocrinol 2019 Jun;35(6):502-505.

[99] Scott EL, Kroenke K, Wu J, Yu Z. Beneficial Effects of Improvement in Depression, Pain Catastrophizing, and Anxiety on Pain Outcomes: A 12-Month Longitudinal Analysis. J Pain2016;17(2):215-22.

[100] Rodgers M, Dalton J, Harden M, Street A, Parker G. Integrated care to address the physical health needs of people with severe mental illness: a rapid review. Southampton (UK): NIHR Journals Library, 2016.

[101] Kramer I, Simons CJP, Hartmann JA, Menne-Lothmann C, Viechtbauer W, Peeters F, et al. A therapeutic application of the experience sampling method in the treatment of depression: a randomized controlled trial, World Psychiatry 2014; 13(1):68-77.

[102] Agar-Wilson M, Jackson T. Are emotion regulation skills related to adjustment among people with chronic pain, independent of pain coping? Eur J Pain 2012;16:105-114.

[103] Leue C, Kruimel J, Vrijens D, Masclee A, van Os J, van Koeveringe G. Functional urological disorders: a sensitized defence response in the bladder-gut-brain axis. Nat Rev Urol2017;14(3):153-63.

[104] Leue C, Driessen G, Strik JJ, Drukker M, Stockbrugger RW, Kuijpers PM, et al. Managing complex patients on a medical psychiatric unit: an observational study of university hospital costs associated with medical service use, length of stay, and psychiatric intervention. J Psychosom Res 2010;68(3):295-302.

[105] Leue C, Buijs S, Strik J, Lousberg R, Smit J, van Kleef M, et al. Observational evidence that urbanisation and neighbourhood deprivation are associated with escalation in chronic pharmacological pain treatment: a longitudinal population-based study in the Netherlands. BMJ Open 2012;2(4):e000731).

[106] Vrijens D, Drossaerts J, van Koeveringe G, Van Kerrebroeck P, van Os J, Leue C, et al. Affective symptoms and the overactive bladder - a systematic review. J Psychosom Res 2015;78(2):95-108.

[107] Verhagen SJW, Berben JA, Leue C, Marsman A, Delespaul PAEG, van Os J, et al. Demonstrating the reliability of transdiagnostic mHealth Routine Outcome Monitoring in mental health services using experience sampling technology. PLoS One 2017;12(10):e0186294.

[108] van Os J, Verhagen S, Marsman A, Peeters F, Bak M, Marcelis M, et al. The experience sampling method as an mHealth tool to support self-monitoring, self-insight, and personalized health care in clinical practice. Depress Anxiety 2017;34(6):481-93. 


\section{Table/Figure Caption List}

Figure 1. Flow-chart of selection process according to the PRISMA guidelines, 2009 [23]

Figure 2a. Forest plot showing standardized mean differences in depression scores within studies comparing endometriosis patients with healthy controls. This plot shows the pooled standardized mean difference (large diamond shape) and $\mathrm{I}^{2}$ resulting from meta-analysis.

Figure $\mathbf{2 b}$. Forest plot showing standardized mean differences in depression scores within studies comparing endometriosis patients with chronic pelvic pain patients without endometriosis. This plot shows the pooled standardized mean difference (large diamond shape) and $\mathrm{I}^{2}$ resulting from meta-analysis.

Figure 2c . Forest plot showing standardized mean differences in anxiety scores within studies comparing endometriosis patients with healthy controls. This plot shows the pooled standardized mean difference (large diamond shape) and $\mathrm{I}^{2}$ resulting from meta-analysis.

Figure 2d . Forest plot showing standardized mean differences in anxiety scores within studies comparing endometriosis patients with patients with chronic pelvic pain without endometriosis. This plot shows the pooled standardized mean difference (large diamond shape) and $\mathrm{I}^{2}$ resulting from meta-analysis.

Table 1 Characteristics and mean scores of studies in meta-analysis comparing endometriosis patients to healthy controls.

Table 2 Characteristics and mean scores of studies in meta-analysis comparing endometriosis patients to patients with chronic pelvic pain (CPP) without endometriosis.

Table 1 Characteristics and mean scores of studies in meta-analysis comparing endometriosis patients to healthy controls.

\begin{tabular}{|c|c|c|c|c|c|c|c|c|c|}
\hline \multirow[t]{2}{*}{ Study } & \multirow{2}{*}{$\begin{array}{l}\text { Sample } \\
\text { size } \\
\mathrm{E}\end{array}$} & \multirow{2}{*}{$\begin{array}{l}\text { Sample } \\
\text { size }\end{array}$} & \multirow{2}{*}{$\begin{array}{l}\text { Age } \\
\text { (Mean, } \\
\text { SD) } \\
\text { E }\end{array}$} & \multirow{2}{*}{$\begin{array}{l}\text { Age } \\
\text { (Mean, } \\
\text { SD) } \\
\text { Co }\end{array}$} & \multicolumn{3}{|c|}{$\begin{array}{ll}\text { DepressionDepression } \\
\text { score } & \text { score } \\
(\text { Mean, } & \text { (Mean, } \\
\text { SD) } & \text { SD) }\end{array}$} & \multirow[t]{2}{*}{$\begin{array}{l}\text { Anxiety } \\
\text { score } \\
\text { (Mean, } \\
\text { SD) } \\
\text { E }\end{array}$} & \multirow[t]{2}{*}{$\begin{array}{l}\text { Anxiety } \\
\text { score } \\
\text { (Mean, } \\
\text { SD) } \\
\text { Co }\end{array}$} \\
\hline & & & & & $\mathbf{E}$ & Co & PROM & & \\
\hline $\begin{array}{l}\text { As- } \\
\text { Sanie } \\
(2012)\end{array}$ & 17 & 17 & $\begin{array}{l}26.1 \pm \\
1.5\end{array}$ & $\begin{array}{l}25.9 \pm \\
1.6\end{array}$ & $\begin{array}{l}12.5 \pm \\
7.2\end{array}$ & $\begin{array}{l}2.4 \pm \\
2.8\end{array}$ & CES-D & $\begin{array}{l}18.3 \pm \\
4.5\end{array}$ & $\begin{array}{l}12.5 \pm \\
2.3\end{array}$ \\
\hline $\begin{array}{l}\text { Facchin } \\
(2015)\end{array}$ & 110 & 61 & $\begin{array}{l}32.9 \pm \\
2.3\end{array}$ & $\begin{array}{l}27.9 \pm \\
4.4\end{array}$ & $\begin{array}{l}7.7 \pm \\
2.2\end{array}$ & $\begin{array}{l}6.5 \pm \\
3.5\end{array}$ & HADS & $\begin{array}{l}5.9 \pm \\
2.2\end{array}$ & $\begin{array}{l}4.7 \pm \\
3.1\end{array}$ \\
\hline $\begin{array}{l}\text { Friedl } \\
(2015)\end{array}$ & 62 & 61 & $\begin{array}{l}33.4 \pm \\
5.4\end{array}$ & $\begin{array}{l}29.6 \pm \\
7.3\end{array}$ & $\begin{array}{l}5.9 \pm \\
4.5\end{array}$ & $\begin{array}{l}5.7 \pm \\
3.1\end{array}$ & HADS & $\begin{array}{l}3.4 \pm \\
3.8\end{array}$ & $\begin{array}{l}4.2 \pm \\
4.3\end{array}$ \\
\hline $\begin{array}{l}\text { Grundströr } \\
(2018)\end{array}$ & & 55 & $\begin{array}{l}26.2 \pm \\
6.4\end{array}$ & $\begin{array}{l}30.2 \pm \\
5.6\end{array}$ & $\begin{array}{l}8.1 \pm \\
4.6\end{array}$ & $\begin{array}{l}2.3 \pm \\
2.4\end{array}$ & HADS & $\begin{array}{l}9.4 \pm \\
5.4\end{array}$ & $\begin{array}{l}4.6 \pm \\
3.4\end{array}$ \\
\hline $\begin{array}{l}\text { Laganà } \\
(2015)\end{array}$ & 166 & 48 & $\begin{array}{l}36.0 \pm \\
6.0\end{array}$ & $\begin{array}{l}38.4 \pm \\
12.8\end{array}$ & $\begin{array}{l}59.3 \pm \\
12.8\end{array}$ & $\begin{array}{l}52.0 \pm \\
13.0\end{array}$ & SDS & $\begin{array}{l}58.2 \pm \\
11.5\end{array}$ & $\begin{array}{l}50.5 \pm \\
12.9\end{array}$ \\
\hline $\begin{array}{l}\text { Melis } \\
(2015)\end{array}$ & 41 & 40 & $\begin{array}{l}31.5 \pm \\
6.4\end{array}$ & $\begin{array}{l}30.4 \pm \\
5.1\end{array}$ & $\begin{array}{l}14.3 \pm \\
11.9\end{array}$ & $\begin{array}{l}4.7 \pm \\
4.7\end{array}$ & BDI & $\begin{array}{l}17.0 \pm \\
13.0\end{array}$ & $\begin{array}{l}7.4 \pm \\
6.9\end{array}$ \\
\hline $\begin{array}{l}\text { Quiñones } \\
(2015)\end{array}$ & 31 & 36 & $\begin{array}{l}29.1 \pm \\
1.2\end{array}$ & $\begin{array}{l}31.7 \pm \\
2.4\end{array}$ & - & - & - & $\begin{array}{l}2.2 \pm \\
0.8\end{array}$ & $\begin{array}{l}2.0 \pm \\
0.6\end{array}$ \\
\hline $\begin{array}{l}\text { Renaer } \\
(1979)\end{array}$ & 22 & 23 & - & - & $\begin{array}{l}61.8 \pm \\
11.0\end{array}$ & $\begin{array}{l}50.5 \pm \\
9.3\end{array}$ & MMPI & $\begin{array}{l}52.2 \pm \\
9.0\end{array}$ & $\begin{array}{l}44.9 \pm \\
9.3\end{array}$ \\
\hline $\begin{array}{l}\text { Rocha } \\
(2015)\end{array}$ & 24 & 25 & $\begin{array}{l}32.9 \pm \\
9.0\end{array}$ & $\begin{array}{l}35.4 \pm \\
6.7\end{array}$ & $\begin{array}{l}9.6 \pm \\
5.0\end{array}$ & $\begin{array}{l}6.4 \pm \\
4.1\end{array}$ & HADS & $\begin{array}{l}8.3 \pm \\
4.6\end{array}$ & $\begin{array}{l}6.5 \pm \\
5.0\end{array}$ \\
\hline $\begin{array}{l}\text { Shatford } \\
(1988)\end{array}$ & 23 & 212 & 32 & 32 & $\begin{array}{l}4.5 \pm \\
4.2\end{array}$ & $\begin{array}{l}4.6 \pm \\
6.3\end{array}$ & BDI & $\begin{array}{l}33.0 \pm \\
9.2\end{array}$ & $\begin{array}{l}33.9 \pm \\
10.8\end{array}$ \\
\hline
\end{tabular}




\begin{tabular}{|c|c|c|c|c|c|c|c|c|c|}
\hline Study & $\begin{array}{l}\text { Sample } \\
\text { size }\end{array}$ & $\begin{array}{l}\text { Sample } \\
\text { size }\end{array}$ & $\begin{array}{l}\text { Age } \\
\text { (Mean, } \\
\text { SD) }\end{array}$ & $\begin{array}{l}\text { Age } \\
\text { (Mean, } \\
\text { SD) }\end{array}$ & $\begin{array}{l}\text { Depress } \\
\text { score } \\
\text { (Mean, } \\
\text { SD) }\end{array}$ & $\begin{array}{l}\text { nDepre: } \\
\text { score } \\
\text { (Mean } \\
\text { SD) }\end{array}$ & & $\begin{array}{l}\text { Anxiety } \\
\text { score } \\
\text { (Mean, } \\
\text { SD) }\end{array}$ & $\begin{array}{l}\text { Anxiety } \\
\text { score } \\
\text { (Mean, } \\
\text { SD) }\end{array}$ \\
\hline $\begin{array}{l}\text { Shaw } \\
(1995)\end{array}$ & 17 & 38 & $\begin{array}{l}30.9 \pm \\
7.5\end{array}$ & $\begin{array}{l}35.0 \pm \\
4.9\end{array}$ & $\begin{array}{l}11.2 \pm \\
6.6\end{array}$ & $\begin{array}{l}5.7 \pm \\
4.8\end{array}$ & BDI & $\begin{array}{l}43.1 \pm \\
14.5\end{array}$ & $\begin{array}{l}37.5 \pm \\
10.6\end{array}$ \\
\hline $\begin{array}{l}\text { Stratton } \\
(2015)\end{array}$ & 18 & 20 & $\begin{array}{l}32.1 \pm \\
8.0\end{array}$ & $\begin{array}{l}35.4 \pm \\
8.8\end{array}$ & $\begin{array}{l}32.4 \pm \\
16.9\end{array}$ & $\begin{array}{l}14.4 \pm \\
17.1\end{array}$ & DHP & $\begin{array}{l}36.6 \pm \\
17.7\end{array}$ & $\begin{array}{l}19.9 \pm \\
21.0\end{array}$ \\
\hline
\end{tabular}

Table 2 Characteristics and mean scores of studies in meta-analysis comparing endometriosis patients to patients with chronic pelvic pain (CPP) without endometriosis.

\begin{tabular}{|c|c|c|c|c|c|c|c|c|c|}
\hline \multirow[t]{2}{*}{ Study } & \multirow{2}{*}{$\begin{array}{l}\text { Sample } \\
\text { size } \\
\text { E }\end{array}$} & \multirow{2}{*}{$\begin{array}{l}\text { Sample } \\
\text { size }\end{array}$} & \multirow{2}{*}{$\begin{array}{l}\text { Age } \\
\text { (Mean, } \\
\text { SD) } \\
\text { E }\end{array}$} & \multirow{2}{*}{$\begin{array}{l}\text { Age } \\
\text { (Mean, } \\
\text { SD) } \\
\text { CPP }\end{array}$} & \multicolumn{3}{|c|}{$\begin{array}{ll}\text { DepressionDepression } \\
\text { score } & \text { score } \\
\text { (Mean, } & \text { (Mean, } \\
\text { SD) } & \text { SD) } \\
\end{array}$} & \multirow{2}{*}{$\begin{array}{l}\text { Anxiety } \\
\text { score } \\
\text { (Mean, } \\
\text { SD) } \\
\text { E }\end{array}$} & \multirow{2}{*}{$\begin{array}{l}\text { Anxiety } \\
\text { score } \\
\text { (Mean, } \\
\text { SD) } \\
\text { CPP }\end{array}$} \\
\hline & & & & & $\mathbf{E}$ & CPP & PROM & & \\
\hline $\begin{array}{l}\text { As- } \\
\text { Sanie } \\
(2012)\end{array}$ & 17 & 6 & $\begin{array}{l}26.1 \pm \\
1.5\end{array}$ & $\begin{array}{l}24.2 \pm \\
1.9\end{array}$ & $\begin{array}{l}12.5 \pm \\
7.2\end{array}$ & $\begin{array}{l}8.8 \pm \\
2.6\end{array}$ & CES-D & $\begin{array}{l}18.3 \pm \\
4.5\end{array}$ & $\begin{array}{l}16.3 \pm \\
3.9\end{array}$ \\
\hline $\begin{array}{l}\text { Brooks } \\
(2015)\end{array}$ & 31 & 110 & $\begin{array}{l}33.3 \pm \\
13.0\end{array}$ & $\begin{array}{l}33.3 \pm \\
13.0\end{array}$ & $\begin{array}{l}6.0 \pm \\
6.5\end{array}$ & $\begin{array}{l}4.6 \pm \\
7.0\end{array}$ & DASS21 & $\begin{array}{l}5.0 \pm \\
5.8\end{array}$ & $\begin{array}{l}4.5 \pm \\
4.4\end{array}$ \\
\hline $\begin{array}{l}\text { Grundstre் } \\
(2018)\end{array}$ & & 24 & $\begin{array}{l}26.2 \pm \\
6.4\end{array}$ & $\begin{array}{l}26.6 \pm \\
5.7\end{array}$ & $\begin{array}{l}8.1 \pm \\
4.6\end{array}$ & $\begin{array}{l}7.7 \pm \\
4.2\end{array}$ & HADS & $\begin{array}{l}9.4 \pm \\
5.4\end{array}$ & $\begin{array}{l}10.1 \pm \\
3.7\end{array}$ \\
\hline $\begin{array}{l}\text { Low } \\
(1933)\end{array}$ & 40 & 41 & $\begin{array}{l}30.0 \pm \\
7.7\end{array}$ & $\begin{array}{l}35.5 \pm \\
9.2\end{array}$ & $\begin{array}{l}14.4 \pm \\
8.2\end{array}$ & $\begin{array}{l}13.3 \pm \\
8.2\end{array}$ & BDI & $\begin{array}{l}45.8 \pm \\
12.1\end{array}$ & $\begin{array}{l}38.2 \pm \\
13.6\end{array}$ \\
\hline $\begin{array}{l}\text { Peveler } \\
(1996)\end{array}$ & 40 & 51 & $\begin{array}{l}32.2 \pm \\
6.3\end{array}$ & $\begin{array}{l}30.6 \pm \\
7.7\end{array}$ & $\begin{array}{l}0.75 \pm \\
0.83\end{array}$ & $\begin{array}{l}0.84 \pm \\
0.67\end{array}$ & BSI & $\begin{array}{l}0.9 \pm \\
0.8\end{array}$ & $\begin{array}{l}0.88 \pm \\
0.7\end{array}$ \\
\hline $\begin{array}{l}\text { Renaer } \\
(1979)\end{array}$ & 22 & 15 & - & - & $\begin{array}{l}61.8 \pm \\
11.0\end{array}$ & $\begin{array}{l}60.9 \pm \\
13.9\end{array}$ & MMPI & $\begin{array}{l}52.2 \pm \\
9.0\end{array}$ & $\begin{array}{l}54.5 \pm \\
10.0\end{array}$ \\
\hline $\begin{array}{l}\text { Rocha } \\
\text { (2015) }\end{array}$ & 24 & 16 & $\begin{array}{l}32.9 \pm \\
9.0\end{array}$ & $\begin{array}{l}32.7 \pm \\
7.8\end{array}$ & $\begin{array}{l}8.3 \pm \\
4.6\end{array}$ & $\begin{array}{l}10.8 \pm \\
6.7\end{array}$ & HADS & $\begin{array}{l}9.6 \pm \\
5.0\end{array}$ & $\begin{array}{l}10.1 \pm \\
6.9\end{array}$ \\
\hline $\begin{array}{l}\text { Roth } \\
(2011)\end{array}$ & 30 & 78 & $\begin{array}{l}32.1 \pm \\
9.5\end{array}$ & $\begin{array}{l}32.1 \pm \\
9.5\end{array}$ & $\begin{array}{l}15.9 \pm \\
12.1\end{array}$ & $\begin{array}{l}16.2 \pm \\
9.7\end{array}$ & BDI & $\begin{array}{l}0.84 \pm \\
0.7\end{array}$ & $\begin{array}{l}0.90 \pm \\
0.7\end{array}$ \\
\hline $\begin{array}{l}\text { Shaw } \\
(1995)\end{array}$ & 17 & 30 & $\begin{array}{l}30.9 \pm \\
7.5\end{array}$ & $\begin{array}{l}30.6 \pm \\
7.6\end{array}$ & $\begin{array}{l}11.2 \pm \\
6.6\end{array}$ & $\begin{array}{l}11.2 \pm \\
7.6\end{array}$ & BDI & $\begin{array}{l}43.1 \pm \\
14.5\end{array}$ & $\begin{array}{l}42.1 \pm \\
10.2\end{array}$ \\
\hline $\begin{array}{l}\text { Souza } \\
(2011)\end{array}$ & 32 & 25 & $\begin{array}{l}36.1 \pm \\
7.8\end{array}$ & $\begin{array}{l}40.6 \pm \\
8.6\end{array}$ & $\begin{array}{l}15.6 \pm \\
8.2\end{array}$ & $\begin{array}{l}17.5 \pm \\
6.1\end{array}$ & BDI & $\begin{array}{l}26.6 \pm \\
10.2\end{array}$ & $\begin{array}{l}32.4 \pm \\
10.5\end{array}$ \\
\hline $\begin{array}{l}\text { Stratton } \\
(2015)\end{array}$ & 18 & 11 & $\begin{array}{l}32.1 \pm \\
8.0\end{array}$ & $\begin{array}{l}35.9 \pm \\
9.3\end{array}$ & $\begin{array}{l}32.4 \pm \\
16.9\end{array}$ & $\begin{array}{l}35.0 \pm \\
13.5\end{array}$ & DHP & $\begin{array}{l}36.6 \pm \\
17.7\end{array}$ & $\begin{array}{l}45.0 \pm \\
13.7\end{array}$ \\
\hline
\end{tabular}

\section{Hosted file}

BJOG. Figure 1.docx available at https://authorea.com/users/355034/articles/478445depression-anxiety-and-endometriosis-a-systematic-review-and-meta-analysis

Hosted file

BJOG. Figure 2.docx available at https://authorea.com/users/355034/articles/478445depression-anxiety-and-endometriosis-a-systematic-review-and-meta-analysis 